\title{
UJI BIOLOGIS EKSTRAK KASAR DAN ISOLAT ALBUMIN IKAN GABUS (Ophiocephalus striatus) TERHADAP BERAT BADAN DAN KADAR SERUM ALBUMIN TIKUS MENCIT
}

\author{
Oleh: \\ *Matheus Nugroho \\ *) Tenaga Pengajar Fakultas Pertanian Universitas Yudharta Pasuruan
}

\begin{abstract}
Abstrak
Tujuan penelitian ini untuk menentukan kualitas biologis ekstrak kasar dan isolat albumin ikan gabus yang optimal terhadap berat badan dan kadar serum albumin tikus mencit. Analisa data penelitian ini adalah uji kualitas biologis ekstrak kasar dan isolat albumin pada tikus mencit, perbedaan hasil tiap perlakuannya dianalisa dengan Rancangan Acak Kelompok (RAK) faktor tunggal. Hasil terbaik uji kualitas biologis ekstrak albumin kasar dan isolat albumin pada tikus Mencit (Mus musculus L.) adalah berat badan tertinggi $28,48 \mathrm{~g}$, pada mencit yang diberi perlakuan ekstrak albumin kasar. Kadar albumin serum tertinggi 2,22 g/dl pada mencit yang diberi perlakuan ekstrak albumin kasar.
\end{abstract}

Kata kunci : ikan gabus (Ophiocephalus striatus), kualitas biologis ekstrak kasar dan isolat albumin, tikus mencit (Mus musculus L.)

\begin{abstract}
The objective of this study to determine the biological quality of crude extracts and albumin isolates of gabus fish that optimal towards body weight and albumin serum content of murine rodents. Analysis of data of this study is to test the biological quality of crude extract and isolate albumin in rats mice, differences in the results of each treatment group were analyzed by Randomized Design (RAK) a single factor. The best results test of the biological quality of crude albumin extract and albumin isolates in murine rodents (Mus musculus L.) is the highest weight $28.48 \mathrm{~g}$, in rodent treated crude albumin extract. The highest contents of serum albumin $2.22 \mathrm{~g} / \mathrm{dl}$ in rodent treated crude albumin extract.
\end{abstract}

Key words : gabus fish (Ophiocephalus striatus), the biological quality of crude extract and isolate albumin, murine rodents (Mus musculus L.) 


\section{Pendahuluan}

Salah satu protein sederhana dalam plasma darah adalah albumin. Albumin dalam tubuh disintesa di dalam hati dengan jumlah sangat kecil. Kekurangan albumin dalam serum dapat mempengaruhi pengikatan dan pengangkutan senyawa-senyawa endogen dan eksoden, termasuk obat-obatan, karena seperti diperkirakan distribusi obat keseluruh tubuh itu pengikatannya melalui fraksi albumin (Goldstein et al., 1968; Vallner, 1977; Tandra et al., 1988). Jika kadar albumin serum berada dibawah nilai normal, maka fraksi obat yang terikat protein tersebut berkurang, dengan kata lain fraksi obat bebas banyak sehingga keadaan ini dapat menimbulkan pengaruh obat yang tidak diinginkan.

Pengadaan albumin terutama untuk kasus bedah saat ini mencapai 91\%, 2/3 albumin tersebut dipakai di bagian bedah dan sisanya $1 / 3$ bagian dipergunakan untuk penanganan penyakit dalam. Harga serum albumin untuk infus mencapai kurang lebih Rp. 1.500.000,- per botol kemasan $100 \mathrm{ml}-20 \%$ albumin (Alexander et al., 1979; Tullis, 1997).

Ikan gabus diketahui mengandung protein yang lebih tinggi dibandingkan jenis ikan lainnya. Kadar protein ikan gabus mencapai 25,5\%, lebih tinggi dibandingkan protein ikan bandeng $(20,0 \%)$, ikan emas $(16,05)$, ikan kakap (20,0\%), maupun ikan sarden $(21,1 \%)$, Kadar albumin ikan gabus bisa mencapai 6,22\% (Carvalo, 1998).

Hasil penelitian Suprayitno (2003) tentang tingkat kesembuhan luka pada tikus putih yang mengalami penurunan kadar albumin (1,8 g/dl) memberikan hasil yang siginifikan. Uji coba telah dilakukan oleh instalasi gizi dan bagian bedah RSUD. Dr. Syaiful Anwar Malang selama 1979-1998, berupa pemberian filtrat dari $2 \mathrm{~kg} / \mathrm{hari}$ ikan gabus terhadap pasien pasca operasi, ibu yang baru melahirkan dan beberapa pasien luka tusukan, yang mempunyai kadar albumin rendah (2,8 g/dl), selama 2-4 hari terjadi peningkatan albumin tubuh menjadi 4,4-5,5 g/dl (kadar albumin normal tubuh manusia), dan permukaan luka mengalami penutupan. Proses pengukusan tersebut dilakukan pada suhu air mendidih (Soemarko, 1997).

Para praktisi kesehatan telah memanfaatkan ekstrak ikan gabus sebagai makanan tambahan (menu ekstra) untuk penderita terindikasi hipoalbuminemia, luka bakar, dan diet setelah operasi. Dari berbagai studi kasus dan penelitian diketahui 
bahwa ekstra ikan gabus secara nyata dapat meningkatkan kadar albumin pada kasus-kasus albuminemia dan mempercepat proses penyembuhan luka pada kasus pasca operasi (Asikin, 1999; Sugihastutik, 2002; Nilasanti, 2003). Mudjiharto (2007) menjelaskan bahwa ikan gabus merupakan bahan sumber albumin yang potensial. Albumin ikan gabus dapat digunakan sebagai biofarma dan bahan substitusi albumin manusia. Agustini (2006) menjelaskan bahwa albumin ikan gabus secara nyata dapat meningkatkan kadar albumin serum dan mempercepat penutupan luka pada tikus percobaan.

Pengaruh perlakuan suhu tinggi menyebabkan perubahan melemahnya enzim proteinase dan nilai daya cerna protein (Nielsen et al., 1988; Deshpande and Damodaran, (1989). Perlakuan panas pada albumin akan menghasilkan perubahan struktur yang tidak dapat balik (irreversible), yang terlihat dengan meningkatnya protein yang tidak larut dalam air. Pengaruh perlakuan panas pada struktur albumin juga dapat melepaskan terbukanya struktur albumin, sehingga diperlukan perlakuan panas yang tepat pada struktur protein tersebut (Stryer, 1981; Slavik, 1982;
Arakawa et al., 1991; Wicker et al., 1986 dan Arntfield et al., 1989).

Albumin, sebagaimana protein umumnya sangat retan terhadap pengaruh suhu, sehingga penerapan suhu yang tepat sangat diperlukan dalam proses untuk menghasilkan ekstrak ikan yang berkualitas baik. Karena pemanasan akan mempengaruhi permiabilitas dinding sel sehingga proses pengeluaran plasma dari jaringan bisa lebih cepat. Penerapan suhu proses antara $70-80^{\circ} \mathrm{C}$ memberikan hasil yang baik. Pemanasan pada suhu $90^{\circ} \mathrm{C}$ selama 10 menit telah menggumpalkan sebagian besar protein plasma, sehingga tidak dapat diekstrak (de Man, 1977).

Berdasarkan

hasil

penelitian pada ikan gabus dan ikan tomang didapatkan kadar albumin sebesar 1332,7 mg/100 g dan 1188,05 mg/100 g (Carvallo, 1998). Analisa kadar albumin pada filtrat ikan gabus hasil pengukusan suhu $98^{\circ} \mathrm{C}$ adalah 19,4\% (Martini, 1998). Hasil analisa sterilisasi ikan gabus pada suhu $121^{\circ} \mathrm{C}$ selama 25 menit didapatkan kadar albumin filtrat adalah $116,419 \pm 22,660 \mathrm{mg} / 100 \mathrm{~g}$ (Hidayati, 1999).

Hal ini semua memperkuat alasan untuk memperoleh isolat albumin hasil ekstraksi secara pengukusan ikan gabus untuk diuji kualitas biologis terhadap tikus mencit. Ekstrak albumin ikan gabus 
diharapkan dapat sebagai pengganti serum albumin impor dalam upaya membantu mempertahankan dan meningkatkan nilai gizi dan kesehatan manusia, sehingga dapat mengurangi anggaran biaya kesehatan yang makin mahal.

\section{Materi dan Metode}

Peralatan yang dipergunakan pembuatan ekstrak kasar ikan gabus antara lain : pisau, gunting, waterbath, thermokopel, thermometer $100^{\circ} \mathrm{C}$, timbangan gelas ukur, kain saring, plastik dan press hidrolik. Peralatan untuk analisa kadar albumin antara lain : kuvet diameter $1 \mathrm{~cm}$, Shimadzu spectrophotometer UV-100-02 dan spectrophotometer

SMA autoanalyzer.

Kolom filtrasi gel ukuran $(2,5 \times 60 \mathrm{~cm})$ dengan bahan isian sephadex G-75 untuk memurnikan ekstrak kasar albumin.

Bahan-bahan yang digunakan untuk ekstraksi adalah ikan gabus yang diperoleh dari bendungan Karangkates dalam keadaan hidup dan aquadest. Bahan untuk uji kadar albumin menggunakan metode brom cresol green adalah

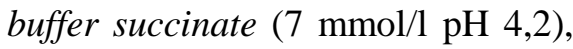
brom cresol green $0,15 \mathrm{mmol} / \mathrm{l}$, brij 35 dan aquadest dapar succinate (0,01 M; pH 4,2), untuk kadar albumin setelah pemurnian kolom filtrasi gel pengujiannya dengan
UV, bahannya antara lain BSA standar 0,5 g/l, buffer phosphat 0,1 $\mathrm{M} \mathrm{pH} \mathrm{7,1} \mathrm{dan} \mathrm{aquadest.}$

Bahan yang digunakan untuk pemurnian ekstrak kasar albumin terdiri dari $1 \mathrm{~g}$ sephadex G-7, buffer phosphat (0,1 M pH 7,1), glasswool dan natrium azid $0,2 \%$.

Analisa data yang digunakan dalam penelitian adalah uji kualitas biologis ekstrak kasar dan isolat albumin pada tikus mencit, perbedaan hasil setiap perlakuannya dianalisa dengan Rancangan Acak Kelompok (RAK) faktor tunggal.

\section{Hasil dan Pembahasan}

Berdasarkan Tabel 1. Menunjukkan bahwa berat badan dan kadar albumin serum tikus mencit, sebagai parameter status gizi mengalami peningkatan setelah pemberian ekstrak kasar ikan gabus $15 \mathrm{ml} /$ hari. Berat badan tikus setelah diberi makan gaplek dan isolat albumin ikan gabus (setelah pemurnian kolom filtrasi gel sephadex G-75) bertambah 5,4\% dibandingkan berat badan sebelum perlakuan, dan bertambah 32\% dibandingkan berat badan tikus kontrol (diberi pakan gaplek, tanpa ekstrak kasar ataupun isolat albumin). Begitu juga dengan tikus yang diberi perlakuan pakan gaplek dan ekstrak kasar (tanpa pemurnian), berat badan bertambah $14,9 \%$ dibandingkan berat badan 
sebelum perlakuan, dan bertambah $58 \%$ dibandingkan berat badan tikus kontrol, sementara berat badan tikus kontrol mengalami penurunan 22,7\%, jika dibandingkan berat badan sebelum perlakuan.

\section{Tabel 1. Berat Badan dan Kadar Albumin Serum Tikus Mencit setelah perlakuan 15 hari $(n=18)$}

\begin{tabular}{|ll|c|c|c|}
\hline \multirow{2}{*}{ Ransum Pakan } & \multicolumn{2}{|c|}{ Berat Badan $(\mathrm{g})$} & \multirow{2}{*}{$\begin{array}{c}\text { Kadar Albumin } \\
(\mathrm{g} / \mathrm{dl})\end{array}$} \\
\cline { 2 - 3 } & Pra & Pasca & $1,95 \mathrm{~b}$ \\
1. & $\begin{array}{l}\text { Gaplek + air putih }+ \\
\text { isolat albumin (n1) }\end{array}$ & 22,67 & $\begin{array}{c}23,89 \mathrm{~b} \\
(5,4 ; 32) \%\end{array}$ & $(33 \%)$ \\
\hline 2. & $\begin{array}{l}\text { Gaplek + air putih }+ \\
\text { ekstrak kasar (n2) }\end{array}$ & 24,79 & $\begin{array}{c}28,48 \mathrm{c} \\
(14,9 ; 58) \%\end{array}$ & $\begin{array}{c}2,22 \mathrm{~b} \\
(51 \%)(14 \%)\end{array}$ \\
\hline 3. & Gaplek + air putih & 23,35 & $18,04 \mathrm{a}$ & $1,47 \mathrm{a}$ \\
& & $(22,7 \%)$ & $(0 \%)$ \\
\hline & & & $\mathrm{BNT}(\alpha=0,01)$ & BNT $(\alpha=0,01)$ \\
\hline
\end{tabular}

Keterangan :

angka berat badan dan kadar albumin yang diikuti dengan huruf yang sama pada kolom yang sama adalah tidak berbeda nyata, pada uji BNT $(\alpha=0,01)$

- Pra = pra perlakuan; pasca $=$ paska perlakuan

- Gaplek dan air putih diberikan ad libitum (tidak terbatas)

- Ekstrak kasar dan isolat albumin yang diberikan $=15 \mathrm{ml} / \mathrm{hari}$

- $\mathrm{n} 1=$ tikus percobaan $1 ; \mathrm{n} 2=$ tikus percobaan $2 ; \mathrm{nc}=$ tikus kontrol

Protein rendah $(15 \%)$, dapat menurunkan secara bermakna berat badan tubuh hewan coba itu. Pengurangan berat badan ini terutama disebabkan karena berkurangnya lemak tubuh akibat konsumsi lemak yang terbatas di dalam gaplek $(0,7 \%)$. Beberapa peneliti tersebut menyatakan bahwa ada korelasi yang tinggi $\quad(r=0,90-$
0,97) antara lemak tubuh dan berat badan. Pertambahan berat badan untuk tikus yang diberi ekstrak ikan gabus (ekstrak kasar ataupun isolat albumin), diduga karena kandungan lemak ekstrak ikan gabus cukup memadai untuk konsumsi tubuh, yaitu $1,7 \%$ berat basah dan $4 \%$ berat kering (Sediaoetama, 1985). 
Hasil analisis ragam (Tabel 1.) menunjukkan bahwa perlakuan ransum pakan yang berbeda, yaitu kombinasi gaplek dan ekstrak ikan gabus (isolat albumin dan ekstrak kasar), dengan yang hanya diberi gaplek, ternyata berpengaruh sangat nyata terhadap berat badan tikus ( $\alpha$ $=0,01$ ).

Berdasarkan data (Tabel 1.) menunjukkan bahwa berat badan tikus tertinggi adalah 28,48 g, dan terjadi pada perlakuan kombinasi antara gaplek dan ekstrak kasar, sementara untuk perlakuan kombinasi gaplek dan isolat albumin berat badan adalah $23,89 \mathrm{~g}$.

Berdasarkan data (Tabel 1.) menunjukkan bahwa kadar albumin serum tikus untuk perlakuan kombinasi pakan gaplek dan isolat albumin (setelah pemurnian kolom filtrasi gel sephadex G-75), bertambah 33\% dibandingkan kadar albumin serum tikus kontrol (gaplek tanpa ekstrak ikan gabus). Begitu juga kadar albumin serum tikus untuk perlakuan kombinasi pakan gaplek dan ekstrak kasar, jika dibandingkan dengan tikus kontrol hasilnya bertambah $51 \%$, sementara bila kadar albumin serum tikus hasil perlakuan kombinasi pakan gaplek dan isolat albumin hasilnya bertambah $14 \%$. Bertambahnya kadar albumin serum tikus setelah diberi ekstrak ikan gabus (ekstrak kasar dan isolat albumin), diduga adanya asam-asam amino penyusun albumin yang terdapat pada ekstrak ikan gabus, sementara berkurangnya kadar albumin serum tikus kontrol, bila dibandingkan dengan tikus percobaan yang diberi perlakuan ekstrak ikan gabus adalah karena akibat kandungan protein (albumin) dalam gablek sangat kurang. Rusli et al. (2006) menjelaskan hasil penelitian mengenai peningkatan kadar albumin pada tikus putih setelah pemberian ekstrak ikan gabus 2 $\mathrm{ml} / 200 \mathrm{~g}=0,36 \mathrm{~g} / \mathrm{dl}$; ekstrak ikan gabus 2,5 $\mathrm{ml} / 200 \mathrm{~g}=0,56 \mathrm{~g} / \mathrm{dl}$; ekstrak ikan gabus $3 \mathrm{ml} / 200 \mathrm{~g}=1,0$ g/dl. Ekstrak ikan gabus dapat meningkatkan kadar albumin tikus putih yang telah mengalami kerusakan hati akibat induksi karbontetraklorida.

Pike and Brown (1984), menjelaskan dalam penelitiannya, bahwa pengurangan kadar albumin serum tikus setelah diberi diet gaplek adalah akibat konsumsi asam amino yang sangat kurang dan dalam waktu yang relatif lama, sehingga sintesis protein albumin oleh hepar mengalami hambatan. Pada saat pembedahan untuk pengambilan darah, secara visual terlihat adanya kecenderungan cardiac vascular tikus kontrol mudah pecah, hal tersebut diduga tikus dengan kadar proteinnya yang rendah, ketahanan tubuhnya 
menjadi berkurang. Koneman tikus mudah terserang infeksi, (1971), menjelaskan dalam sehingga menurunkan kondisi penelitiannya bahwa tikus yang normal albumin serum. Suryadi et lapar gizi, individu tersebut al., (1991) menjelaskan bahwa cenderung mudah terserang infeksi. menurunnya sintesa albumin karena Peningkatan kadar albumin serum tikus yang diberi ekstrak kasar mencapai 51\%, hal ini diduga kandungan protein ekstrak kasar masih kompleks dan tinggi (protein globulin dan lipoprotein), dengan komposisi asam amino yang relatif masih lengkap, yang meliputi asam amino esensial dan asam amino non esensial dibandingkan isolat albumin. Buchanan (1978), melaporkan bahwa pengurangan albumin serum tikus juga dipengaruhi oleh hambatan sintesa fraksi globulin oleh hepar, sebab pada kondisi kadar globulin turun akibat kurang gizi, hal tersebut dapat tercermin dari kadar biokimia darah, yang meliputi turunnya fraksi-fraksi albumin, globulin, lipoprotein dan total protein dalam tubuh.Tandra et al. (1988), menyatakan bahwa asam amino utama penyusun albumin adalah asam aspartat dan glutamat. Suprayitno (2003), menyatakan kadar asam amino tertinggi dalam albumin ikan gabus adalah asam glutamat, leusin dan asam aspartat, seperti tersaji pada Tabel 2. 
Jurnal Teknologi Pangan Vol.5 No.1

Juni 2013

Tabel 2. Kadar asam amino dalam albumin yang terdapat 100 gram dari setiap gram bagian yang dapat dimakan Ikan gabus

\begin{tabular}{|c|l|c|}
\hline NO & \multicolumn{1}{|c|}{ Jenis Asam Amino } & Albumin Ikan Gabus (\%) \\
\hline 1 & Fenialanin & 7,5 \\
\hline 2 & Isoleusin & 8,34 \\
\hline 3 & Leusin & 14,98 \\
\hline 4 & Metionin & 0,81 \\
\hline 5 & Valin & 8,66 \\
\hline 6 & Treonin & 8,34 \\
\hline 7 & Lisin & 17,02 \\
\hline 8 & Histidin & 4,16 \\
\hline 9 & Asam Aspartat & 17,02 \\
\hline 10 & Asam Glutamat & 30,93 \\
\hline 11 & Alanin & 10,07 \\
\hline 12 & Prolin & 5,19 \\
\hline 13 & Serin & 11,02 \\
\hline 14 & Glisin & 6,99 \\
\hline 15 & Sistein & 0,16 \\
\hline 16 & Tirosin & 7,49 \\
\hline
\end{tabular}

Sumber : Suprayitno (2003)

Hasil analisis ragam (Tabel 1.) menunjukkan bahwa perlakuan ransum pakan berbeda, yang meliputi gaplek dengan ekstrak ikan gabus (isolat albumin dan ekstrak kasar), dan yang hanya diberi gaplek, ternyata berpengaruh sangat nyata terhadap kadar albumin serum tikus $(\alpha=0,01)$, tetapi untuk perbandingan antara perlakuan kombinasi gaplek dan isolat albumin dengan gaplek dan ekstrak kasar, hasil analisis ragam tidak berbeda nyata, hal ini menunjukkan bahwa meskipun kedua jenis ekstrak ikan gabus mempunyai kadar albumin yang berbeda yaitu $1,77 \mathrm{mg} / \mathrm{g}$ untuk isolat albumin, dan $152 \mathrm{mg} / \mathrm{g}$ untuk ekstrak kasar, namun karena proses absorpsi protein terlarut dalam saluran cerna tubuh tikus menghasilkan kadar albumin serum tikus yang tidak berbeda nyata, artinya secara kuantitas protein dalam isolat albumin hasil pemurnian kolom filtrasi gel sephadex G-75 jauh lebih mudah terabsorpsi dalam 
saluran cerna tikus, dibandinkan protein ekstrak kasar.

\section{Kesimpulan}

Uji kualitas biologis ekstrak albumin kasar dan isolat albumin pada tikus Mencit (Mus musculus L.) adalah berat badan tertinggi 28,48 g, pada mencit yang diberi perlakuan ekstrak albumin kasar. Kadar albumin serum tertinggi 2,22 g/dl pada mencit yang diberi perlakuan ekstrak albumin kasar.

\section{Saran}

Berdasarkan hasil terbaik penelitian tersebut diatas, disarankan untuk dilakukan penelitian lanjutan lainnya yang terkait yaitu bagaimana pengaruh ekstrak albumin ikan gabus terhadap kadar protein dan perkembangan pembentukan jaringan sel baru akibat luka pada tikus mencit

\section{Daftar Pustaka}

Agustini, D.F., 2006. Pengaruh Pemberian Serbuk Albumin Ikan Terhadap Penutupan Luka Pada Tikus Putih Wistar (Rattus novergicus). Fakultas Perikana. Universitas Brawijaya. Malang. Tidak Diterbitkan. Hal. 102

Alexander, M.R. J.J. Ambre, B.I. Liskon and D.C. Trash, 1979.
Therapeutic Use Of Albumin. JAMA., 241 : 2527-2529.

Arakawa, T., Y.A. Kita and L. Narhi, 1991. Protein-Ligand Interaction as a Method to Study Surface Properties of Proteins. Pages 87-125 in: Methods of Biochemical Analysis. C. H. Suelter, ed. J. Wiley \& Sons: New York Arntfield, S.D., E.D. Murray, M.A.H. Ismond and A.M. Bernatsky, 1989. Role of The Thermal DenaturationAggregation Relationship in Determining The Rheological Properties of Heat Induced Networks for Ovalbumin and Vicilin. J. Food Sci. 54: 1624-1631

Asikin, A., 1999. The Impact of Snakehead Filtrate Extra Menu Administration for Pre and Post-operative Patients in Saiful Anwar General Hospital Malang, (Thesis). (in Indonesian)

Buchanan, N., 1978. Drug Kinetics in Protein - Energy Malnutrition. S. Afr. J. Med., Page. 53:327

Carvallo, Y. N., 1998. Study Profit Asam Amino, Albumin, Mineral Zn pada Ikan Gabus (Ophiocephalus sriatus) dan Ikan Tomang (Ophiocephalus 
Micropeltus). $\quad$ Fakultas Perikanan. Universitas Brawijaya. Malang. Hal 2830.

De Man, J. M., 1997. Kimia Pangan. Edisi 2. Penerbit Institut Teknologi Bandung. Bandung. 550 hal

Deshpande, S.S. and S. Damodaran, 1989. Structure Digestibility Relationship of Legume Proteins. J. Food Sci., 54: 108-113

Goldstein, A., L. Aronow and S. M. Kalman, 1968. Principles of Drug Action-The Basis of Pharmacology. New York. Page, 45-112.

Hidayati, O., 1999. Study Kadar Albumin, Zn dan TVB Filtrat Ikan Gabus (Ophiocephalus sriatus) pada Lama Sterilisasi dan Penyimpanan yang Berbeda. Laporan Penelitian. Fakultas Perikanan.

Universitas Malang. Hal 36.

Koneman, E.W., Brawijaya.

Inflammation. 1971.

Mincler, J., H.B. Anstall dan T.M. Mincler (eds) Pathobiology = an Introduction. The C.V. Mosby Co. St. Louis. Page. 184-204

Martini, N. D., 1998. Pengaruh Lama Pengukusan Terhadap Kandungan Albumin, Asam
Amino dan Zn pada Ikan Gabus (Ophiocephalus sriatus). Laporan Penelitian. Fakultas Perikanan. Universitas Brawijaya. Malang. Hal. 36.

Mudjiharto, 2007. Fish as Human Serum Albumin Substitute. http://www.prasetya.brawijay a.ac.id. Retrieved 18 August 2009

Nielsen, S., 1998. Food Analysis. London. Glisers

Nilasanti, I., 2003. Administration of Snakehead Fish as an Extra Menu for Hypoalbuminemia Patient in Bapelkes Ward General Hospital Ngudi Waluyo Wlingi, Blitar. (Thesis), Polytechnic of Health $\mathrm{MoH}$ Malang. (in Indonesian)

Pike, R. and M. Brown, 1984.

Nutrition: an integrated approach. New York:

Macmillan

Rusli, Jumain dan M. Saud. 2006. Terapi Albumin dalam Ekstrak Ikan Gabus Terhadap Kerusakan Hati Tikus Putih. Jurusan Farmasi Politeknik Kesehatan Makasar. Hal. 9598

Sediaoetama, A.D., 1985. Ilmu Gizi. Jilid 1. Dian Rakyat. Jakarta. Hal : 10-125

Slavik, J., 1982. Anilinonaphtalene Sulphonate as a Probe of 
Membrane Composition and Function. Biochim. Biophys. Acta, 694, 1-25

Soemarko, 1997. Pengaruh Diet Ikan Kutuk dan Telur Terhadap Peningkatan Albumin dan Penutupan Luka Operasi. Rumah Sakit Dr. Saiful Anwar. Malang. Hal 1-28.

Stryer, L., 1981. Biochemistry. 2nd. 949 pp. San Fransisco:W.H. Freeman \& Co.

Sugihastutik, 2002. Administration of Snakehead Fish Filtrate for Hypoalbuminemia Patients in General Hospital Dr. Subandi Jember (Thesis). Polytechnic of Health $\mathrm{MoH}$ Malang. (in Indonesian)

Suprayitno, E. 2003. Penyembuhan Luka dengan Ikan Gabus. Fakultas Perikanan. Universitas Brawijaya. Malang
Suyardi, A., S. Sayogo dan E.R. Soegih, $1996 . \quad$ Kadar Biokimia Darah pada Wanita Hamil Trimester III dengan Keadaan Gizi Kurang di Rumah Sakit Bersalin DKI Jaya. J. Medika

Tandra, H., H.W. Soemartono dan A. Tjokroprawiro, 1988. Metabolisme dan Aspek Klinik Albumin. J. Med., 3 : 249-258.

Tullis, J. L., 1997. Albumin 2 Guidelines for Clinical Use. JAMA., 237 : 460-463.

Vallner, J. J., 1977. Binding of Drugs By Albumin and Plasma Protein. J. Pharm Sci., 66 ; 447-449.

Wicker, L., T.C. Lanier, D.D. Hamann and T. Akahane, 1986. Thermal Transitions in Myosin-ANS Fluorescence and Gel Rigidity. J. Food Sci. 51: 1540-1543, 1562 